\title{
食品污染物モニタリングシステム
}

人為的に非天然物質を自然界に導入した結果, PCB 污染の例のように最終的にヒトの生活をる脅か すことが認識されてから，食品の污染に人々の関心が集まっている．しかし，何を標準とすれば良い のだろらか.ヒトは，とくに日本人はまさに雑食性の動物であって, 利用する食料も雑多を極め, そ れぞれ異なった環境の過去を持っている.モニタリングのデータの蓄積と解析はともすると普遍性が ないといわれるが，計画性と継続性が備われば今後の人間生活に有益であることは間違いない。

内 山 充 Mitsuru UCHIYAMA 国立衛生試験所

食品污染物のモニタリングは, 現代の health science の integral part を占めている. それは, 健康に有害な 污染物質がわれわれの体内にとり込まれる場合，90\%近 くが食品経由であるという事実と, 現在の人体-曝露の 実態を知り，さらに将来の推移を予測する最も的確な方 法であることと，そこから污染物に関するすべての毒理 学 (toxicology) の研究の根拠が得られ, 研究成果の意 義づけが行なわれるという大きな役割を果たしらるから である.

ここでは, 食品污染物モニタリングの意義, 国際的動 向, 国内のモニタリングシステム作成の経緯, およびデ 一タ集計結果の一端を解説する.

\section{1. 食品衛生における毒理学の必然性}

学問発展の原動力は人々の持つ疑問と希望である. 研 究者は, それらの疑問に答えられるように真理を探究し， 原理を明らかにしようとする. また，希望に応えられる ように技術を開発し，環境を改良し，物質を生産する。 その結果, 知識は豊かになり生活は向上した。しかし, その間に出現した諸物質は，それらの特色や効果が充分 検討され，理解されてきたのに比へてて，それらのために 人間生活が将来劦やかされるかも知れない可能性につい ては，徹底的には検討されずに終ってきた，それはむし ろ, 学問発展から見れば後向きの行為であるといらそし りさえ受けた。過去の食塩電解, 採鉱治金, 農薬, 医薬, PCB，あるいは原子力利用の歴史がそれを明らかに物語
ク，今後きたるべきビックサイエンスもその例外ではな い. それらの結果としてもたらされた環境や食品の污染, 人間への危害については事新しくいらまでもない。

今日に怙いては, 人々は生活, 文化の向上発展と並ん で環境の安全性, 健常性を同時に求めているといっても よい.そこに毒理学の分野が開け, 障害性と安全性を見 きわめるための手段として各種の物質と生体との相互作 用に関する研究が一斉に行なわれるようになってきた。

\section{2. 毒理学におけるモニタリングの意義}

ところで, 分析化学的方法で食品中に有害污染物の存 在が検知されたということと，その食品が有害であると いうことでは大きな差がある.その污染物固有の毒性の 他に, 食品中の存在量と存在形態, 共存食品成分, 污染 食品の摂取量および生体側の脆弱性や応答力といった要 因が総合されて，最終的にその食品の人体に対する影響 の度合が表わされる. 安全性の評価が毒性試験の単純な 裏がえしではない所以である.

これらの要因のらち, 存在量, 存在形態, 共存成分, 摂取量は，まさにモニタリングによって得られる実態値 であるから，モニタリングが不充分では現状における安 全性評価は不可能となる.

実験科学者は, 自らの実験計画を立てる前に, 関連し た既存の報告の内容を充分検討して自分の実験の新規性 を確認するのは当然である. しかし，その実験が分析化 学, 生化学, 薬理学など基礎の学問的興味に止まらず, 
得られた成果を環境改良に役立たせたり，危害防止対策 上に利用したり，あるいは安全性評価の根拠としたい時 には，あらかでめ新規性を調查しておくだけでは不充分 であって，さらに現実性が加味されなければならない。 したがって, 前記要因の中の生体側の脆弱性や応答力に 関する実験として, 污染物による組織变化や酵素阻害, あるいは代謝活性の変動や免疫活性の変化などを動物実 験で求めようとするに当っては, 使用する污染物は実態 に近い濃度, 形態, 共存状態にするか, あるいは確実に それらを外挿しらるものを用いなければならないことに なる.それゆえ，実態が把握されていないと，これらの 実験計画を立てる上にも致命的支障をきたすこととなる. この意味でもモニタリングの持つ意義は大きい。

\section{3. バッククラウンドとその意㲔}

生命のしくみの中において, 生体の一部の主要成分に ついての生合成や代謝の詳細が明らかにされ, エネルギ 一生産や感覚応答, あるいは形質発現の機構む解明され つつあるが，“健康” の尺度や “正常”な状態の分子レ ベルでの定義はない。

一方, われわれの周囲の環境因子の中で，危険度や障 害性が完全にゼ口というものはない，水や酸素をはじめ として, 生体必須の微量元素などでも, 量と化学形が異 常であれば必ず障害性を持つ。

この 2 つの理由から, 正常も健康も安全も尺度はすべ て“比較”の上に立って行なわれている.85歳までしか 生きられなければ，人類の寿命（115 年）から見れば不 健康であるのに, 他人との比較で見れば充分健康である. 食品の安全性の評価も，多くの要因を総合的に考える 必要があるとはいえ，最終的には比較の上に立って行な われる.その時の比較すべき基準として最も信頼性の高 いものは，人間が何百年もの間継続して食べ続けてきた 旧来の食品である．污染物の量や質がこれら既往の食品 に扩ける状態,すなわちバックグラウンド值と比較して 好ましからざる傾向になければ，その污染物固有の毒性 が新たに発見された場合を除いてすずは安全といら評価 をする.

このような判断の基準となるバックグラウンド值は, 広い地域を対象として求められなければならないし，ま た経年推移も明らかでなければならない，信頼しらるバ ックグラウンド值は, かなりの規模と計画性を持って初
めて得られるすのといえる，また，これまで述べた背景 に立てば，国内はもとより国際的にも，食品中の污染物 のバックグラウンドレベルをモニターすることは, 食品 衛生上欠くことのできない活動であるといらことになる.

\section{4. 国際機関の動き}

1972 年,ストックホルムで開かれた国連の人間環境 会議の決議に基づいて，国連環境計画 (UNEP) が行な っている地球環境調査システム (GEMS) の一環として, $\mathrm{FAO} / \mathrm{WHO}$ 合同の食品および飼料污染物モニタリング 計画が始められたのは，1974(昭和 49) 年であった。そ の後のこの計画の今日までの動向を図1に示したが，具 体的な中味は次の通りである.

\section{1) Phase I}

まず，1974 年の 9 月まで世界各国の食品污染物分析 の実情を調査し, その後さらに会合を重ね, 国際的調查 研究計画を組めるかどうか，どの国がそれに参加しうる か，技術援助の必要性はどの程度かを判断した。

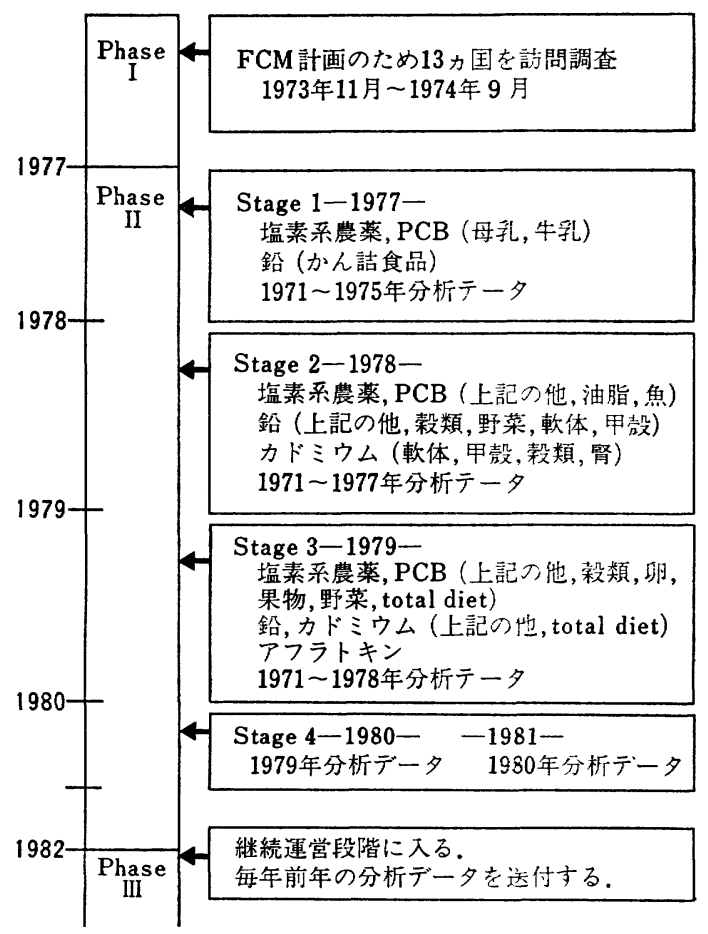

図 1 FAO/WHO $の$ Food and Animal Feed Contamination Monitoring(FCM) 計画の 概略 
1974 年夏には，この謂査のために WHO の委啒を受 けた米国 FDA の Dr. Jelinek がわが国を訪れ，厚生省， 農林水産省, 環境庁をはじめ, 各試験研究機関の担当者 から当時の食品污染物に関するわが国の調査体制や調査 結果などを聞き，報告書にまとめて 1974 年 10 月の第 1 回の検討委員会に提出している. その内容は, 当時のわ が国の技術と体制が国際的に見るとどの程度の水準にあ ったか，を知るのには非常によい資料となる．内容を要 約すると，

(1)食品污染物の分析のための公定法は，国立衛生試験 所などでまとめられ，国の委員会の承認を得た後，厚生 省から告示あるいは通知され，必要に応じて研修会など が開かれている．国内でのクロステェックの習慣はない が，分析結果はほぼ均質 (comparable) である。

(2)分析に関する技術水準はきわめて高く，分析件数も 充分に多い。

(3)モニタリングは, 大部分が地方衛生研究所において 行なわれているが，その結果は各地方で個々に評価され ている，厚生省その他で全国值が評価されているのはそ れらのらちの極く一部である.

(4)数多くある調査データは，コンピュータ処理をまっ たくされていない（厚生省にはコンピュータ施設がない と書いてあるが，これは䛊認である).

(5)日常調理食品からの污染物摂取量調査 (total diet study）が組織的には行なわれていない.

といったものであった.

この観察はかなり正確なものであって, 事実その時代 には，全国的に見ればかなり精力的に食品污染物の分析 がなされ，程度の高いデータが多数生みだされ，それぞ れの地方において実驡の解析や污染の監視に役立ってい たであろらが，国が特別に計画し委託した調査以外は分 析データはそれぞれ地方衛研にそのまま保存され, 全国 集計はまったく行なわれていなかった，乙たがって，食 品別, 污染物別の実態を年次每に集計して推移を見たり， 地域別に集計して比較したり, 污染のバックグラウンド を全国平均（あるいは中央）值として算出することは不 可能であり, データはまったく死藏されていたといって もよい,

また，クロスチェックの習慣のないことと total diet study の欠落も確かに痛いところを指摘されている.

この報告書の指摘がその後のわが国の国内の体制を大
きく変え, 後に述べるシステムを作り上げる原動力にな った.

このように，当時の実情は不充分であったとはいえ， 米，英，加などに次ぐ充足度を示していた（特に母乳の 分析データ数は世界一であった) ので, わが国も計画の 主要メンバーとして Phase II から参加を要請されるこ ととなった。

\section{2) Phase II}

当初は 3 か年計画ではじめられたが，結局1977〜1981 年の 5 か年が Phase II となった. まず, 計画の協力機 関を各国におくこととなり，1977 年にはオーストリア， カナダ, デンマーク，エジプト，西ドイッ，グァテマラ， ハンガリー, アイルランド, 日本，ヶニア，オランダ, ニュージーランド, ポーランド, スウェーデン, スイス, イギリス，アメリカの17か国がそれぞれ協力機関を定め た. わが国では，国立衛生試験所がこれに当っている. その後ブラジル, コロンビア, メキシコ, ソ連も協力国 として参加し，現在は 21 か国が協力している.この計 画は, 毎年定められた食品の, 特定污染物に関するデー タを年次別（試料採取年）に集計し，分析件数，メディ アン值， 90 パーセンタイル值（全データの $90 \%$ がその 值以下である値)をWHO に送付し，それを基にして WHO が地球全体の趨勢をまとめようといらものである.

送付データの種類は図 1 に概略を示した通りだが，各 国から送られるデータの種類や数にはきわめてばらつき が大きく，解析の困難さは並大抵ではなからう．さらに， 各国のデータの均質性にはかなりの疑問がある。そのた め, 1980 年から分析精度確認 (analy tical quality assurance) のための国際クロスチェックも並行して行なわれ ている.これは重金属 $(\mathrm{Pb}, \mathrm{Cd})$ ，塩素系化合物（農薬 と $\mathrm{PCB})$, およびアフラトキシンに関し, 各国 5 つ以内 の機関が参加して同一試料を分析するものである.

わが国であ国立衛試をはじめ主要な衛研がこれに参加 した. 結果は, 当然予想されたことながら，全体ではか なりの幅のばらつきを示した．PCB の分析のできない 国が多いことと，重金属のデータが不揃いなのが目立っ た、わが国は，1，2の例を除きまずまずのよいデータ を得ているが，重金属の部門と PCB の部門で大阪府公 衆衛生研究所が世界一正確な值を出したことは誇りらる べきこととして特筆に值する。 


\section{5. 国内の食品污染物モニタリングシステム}

1969 年秋, 牛乳中に高濃度の $\beta-\mathrm{HCH}(\mathrm{BHC})$ が存在 していることが明らかにされ，さらに，1972 年に PCB の, 1973 年に水銀の暫定規制值が定められたこともあ り, 食品污染物の本格的分析は 1970 年代前半からわが 国では急激に盛んになった。

$\mathrm{FAO} / \mathrm{WHO}$ の上記の計画の有無に関係なく，これま でに積み重ねられた全国の食品衛生関係技術者の貴重な 成績を総集計し, 整理して保存し，さらに必要に応じて 情報として活用することは，国家的見地からいって当然 なすべきことである.

しかし，実際に手をつけるとなると前例のないことで もあり，予算や時間のないままなかなか具体化しない状 態であった.ところが 1977 年, 前記 Phase II への参加 を契機として，多少遅きに失した感はあるとしても，と もかくシステム化の研究計画に一歩を踏みたししたわけで ある・

食品污染物の分析を行なってデータを出している研究 者は，もちろん日本国内に数多い，しかし，毎年同じよ らに計画性をもって，乙かも均質なデータを供給してく れるのは, 地方衛生研究所を措いて他にはない,そこで,
本研究計画の大筋は, 全国の衛生研究所 (国立 3 , 都道 府県 47 , 指定都市 9 (現在は 10), 政令市 11 (現在は 10）の計 70 か所）において，1971 年以降に得られてい るバックグラウンドデータを収集, 処理し,さらに今後 毎年のデータをそれに加えていって食品污染の実態, 推 移, 相関関係を明らかにするとともに，今後の試験研究 の方向や食品污染対策を考察しらるようなデータベース の作成を目標とした．したがって，この計画にはまず衛 生研究所すべての全面的協力を得ることが必要であって, 一部の欠落があっても成果の意義が著しく小さくなる.

筆者は, 今回の計画を実行するに当り, 地方衛生研究 所全国協議会技よびそれに付随する全国衛生化学技術協 議会の組織を通じて主旨の徹底および調查方法の説明な どを行ない, 1978 年 $2 \sim 3$ 月には全国 6 ブロックでの担 当者の集りを歴訪し, 計画細部の打合わせを行なった.

データの集計と処理は厚生省大臣官房統計情報部の大 型コンピュータを用いることとなったが，同部情報企画 課からは終始便宜を与兄られ，好意ある協力を得られた のは大きな幸いであった。

1） テータの記入とコード化

データの集計に用いるカードのデザインは，計画全体

食品污染物モニタリング集尌カード
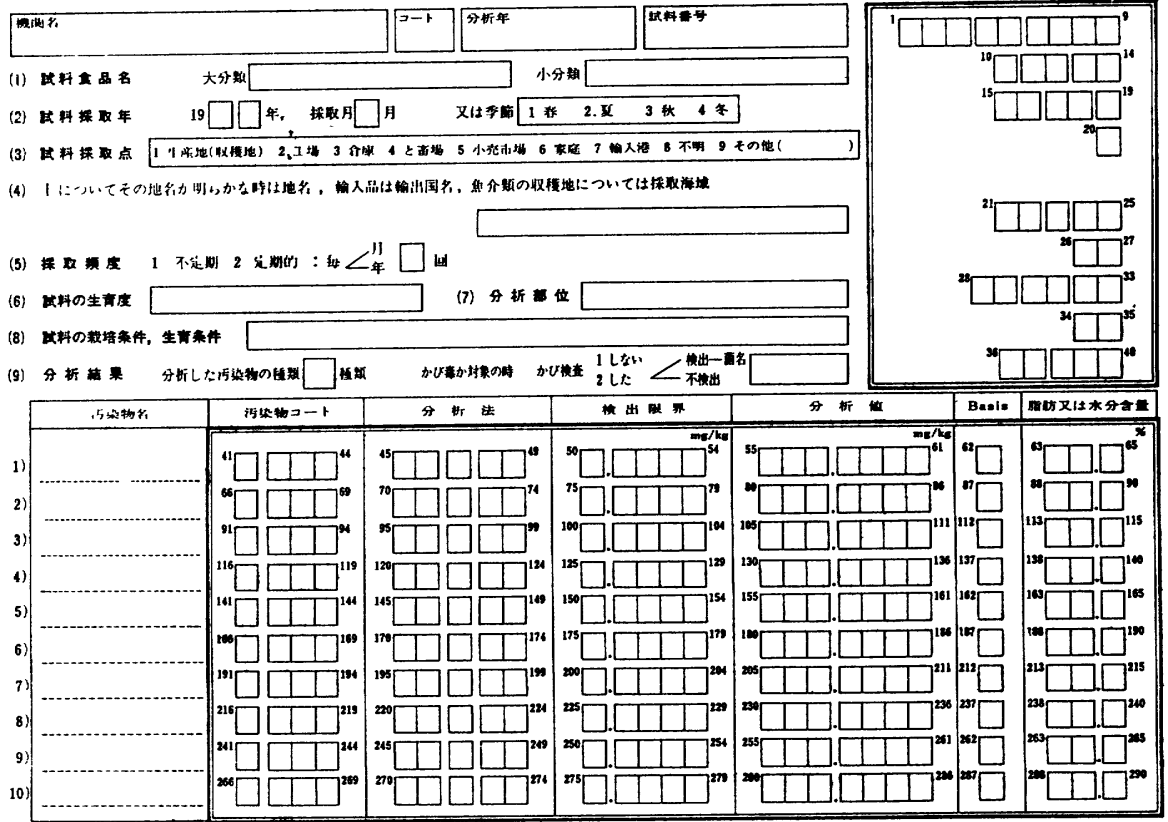

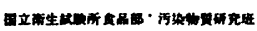

図 2 現在, 食品污染物モニタリンクに使用している集計カート (原寸は A 4 版) 


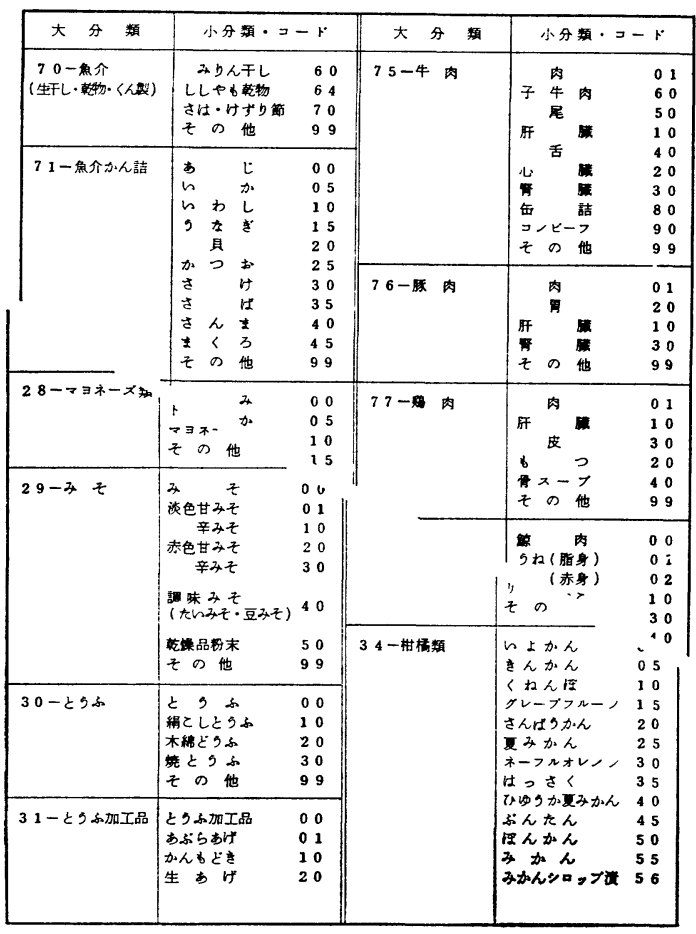

図 3 食品試料コード表の一部

の能率と成否に大きく影響する，しかし，これまでに参 考とすべき前例もなく, 諸外国のものは単純すぎて参考 とならなかった。 また，データ提供の母体となる各機関 がすでにそれぞれ独特の項目と記録法でデータの整理を 行なっていることもあって, コンピュータに入力する項 目, 分類, 数值の記入法, 特に同一試料について多種の 污染物を同時に分析している場合のデータ記入法などに ついては，現場で最も対応しやすい形でデザィンを作り 上げるよう努めなければならなかった。

この目的のために, 全衛生研究所から, 入力可能な項 目 (試料採取年月日, 採取時期, 採取場所, 分析部位, 試料の生育度, 分析法など), あるいは希望する出力の 例などのアンケート回答を求めたりして集計カード作成 の参考とした. そして, 数回に拉よぶワーキンググルー プでの協議の結果, 集計用のカードは, 最初筆者が原案 として提出したものとは似ても似つかぬものになるほど に修正を加えられ，現場で最も記入しやすい形として図 2のように完成した.

最近は, 1 つの分析試料について多項目同時分析を行 ならことが多くなった. そのため, 同一試料で 10 種以 上の污染物を分析した場合はこのカードを 2 枚以上使い,

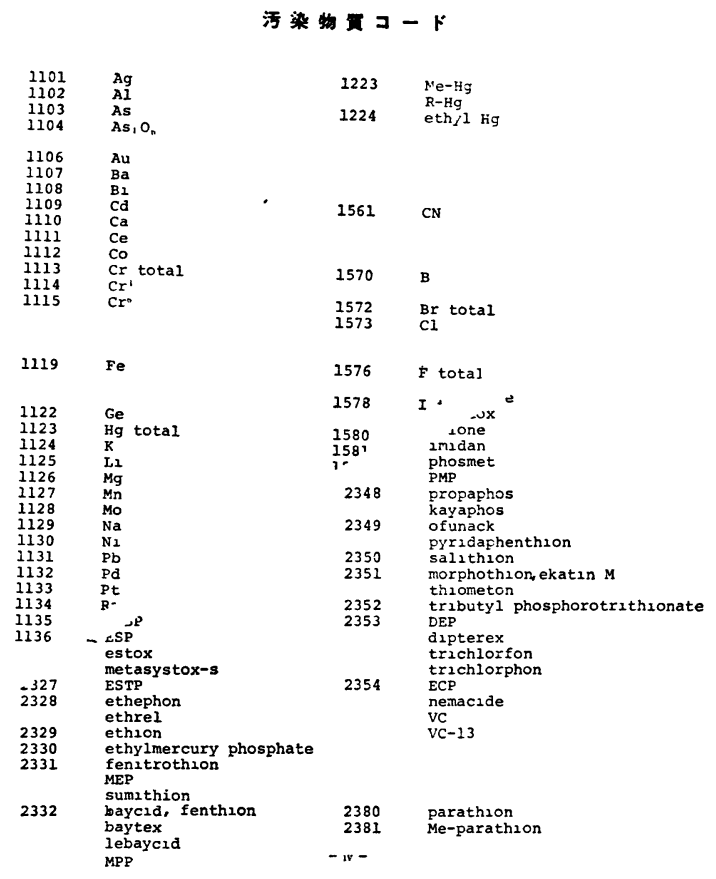

図 4 污染物コード表の一部

上半の ID 部分 $(1 \sim 40)$ は最初の 1 枚にのみ記入する こととした.

このカードを全国の機関に予め送付し, 既存データの 記入を依頼したが，1979年以降は毎年との前年度の分新 データが記入されて筆者の手もとへ送付されている. ま た, カード内の記入事項をコードに変換する作業は, 当 初筆者の研究室で数十万件を処理したが，1979年以降は 一定のコード表とコード化要領に従って各機関でデータ 記入と同時に行なわれている.

食品試料コード（図 3）は，国民栄養調査における食 品分類に基ついて大分類（2妳）し，それをさらに小分 類 (2 妳) したものである. 食品の名称には慣用名も多 いので, 重複しているものもあるかも知れない。また， 加工や保存法の異なるものの分類にも手落ちがあると思 われ, 完全な食品分類は期し難いところである.

污染物コード（図 4) は，化合物の性質によって一㐫 分類してあるが，食品污染物として分析の対象となる機 会のないものは採用していない.なお，現在でも新污染 物の登場に合わせて，このコード表は随時追加されつつ ある.

本年 8 月末までに筆者の手もとに送付を受けたデータ 数は 626,488 件（カード枚数にして約 10 万枚）であり， 
その年次別内訳は，

$\begin{array}{llll}1971 \text { 年 } & 49,332 \text { 件 } & 1976 \text { 年 } & 62,761 \text { 件 } \\ 1972 \text { 年 } & 53,045 \text { 件 } & 1977 \text { 年 } & 65,534 \text { 件 } \\ 1973 \text { 年 } & 60,910 \text { 件 } & 1978 \text { 年 } & 75,059 \text { 件 } \\ 1974 \text { 年 } & 60,117 \text { 件 } & 1979 \text { 年 } & 77,158 \text { 件 } \\ 1975 \text { 年 } & 52,569 \text { 件 } & 1980 \text { 年 } & 62,789 \text { 件 } \\ & & \text { その他 } & 7,204 \text { 件 }\end{array}$

となっている.

\section{2) 入カと出カ}

コード化されたデータを磁気テープとするのは, 外注 そよって行なった. 磁気テープ上のデータのエラーをク リアするプログラムおよび fat basis と as is basis の 变換計算, あるいは $\alpha, \beta, \gamma, \delta-\mathrm{HCH}$ の各データから total $\mathrm{HCH}$ の作成や修正のプログラムなどは統計情報 部佐藤郁雄氏によって作られた. データのエラーチェッ クは随時行なわれているが，原カードについて照合検討 し修正している. 原カードの容積がかなりのものに達し て，そろそろ保管場所の新しいところを探さねばならな いという嬉しい悩みを招来している。

出力方法については, 機関, 年次, 試料種別, 污染物 別, 分析法, 採取場所, 生育度など,カード上の項目によ ってデータの選び出しをした後で，それらの統計（標本

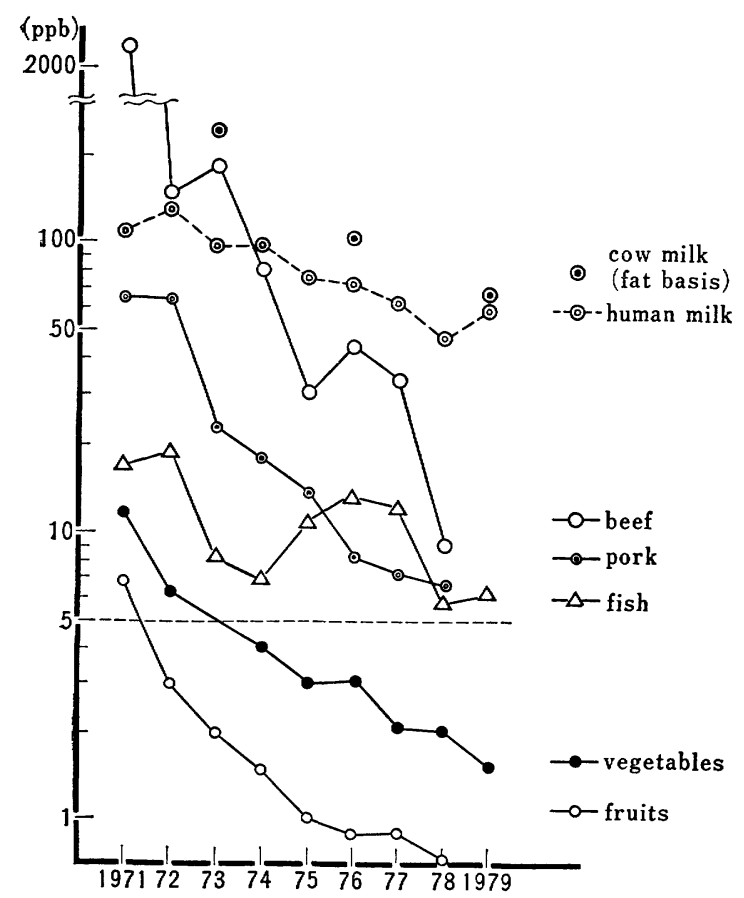

図 5 食品中の総 $\mathrm{HCH}(\alpha, \beta, \gamma, \delta$ 異性体の合計) 濃度の推移 (全国平均値)
数, 最小値, 10 パーセンタイル值, メディアン值, 90 パ 一センタイル值, 最大值, 平均, 標準偏差など）を得たり， ヒストグラム, 相関, クロス集計などを出すことができ るようプログラムを準備した. 現在のところ毎年 WHO へ特定のデータの統計值を送ることと, 全協力機関に主 要データの打出表を送付することの他に, 協力機関から の要請に従い, 随時全国データを作って供給している.

\section{6. モニタリングデータの実例}

\section{1）環境污染物質の年次推移}

食品は原料をすべて動植物など生物にあ打いでいる。 したがって, 生育環境の污染の影響を強くうける. 食品 中の污染物質の推移はそのまま人体曝露の变遷であると いってよい．モニタリングデータを整理して経年的変動 を図示した例を図 5〜7 に示したが，それぞれの時代の われわれの生活環境の污染状態をよく反映している.

いずれの図においても，母乳中の污染物濃度の減少が 他の食品中のものの減少率に比べて著しく遅い，食物連 鎖の高次に位置する人体が最も污染を受けるのは当然の ことであろう.

PCB の魚での含有量が特に高いのは特徽的である. わが国の人体への PCB のとり込みは, ほとんど魚が担 体となっているといっても過言ではない。

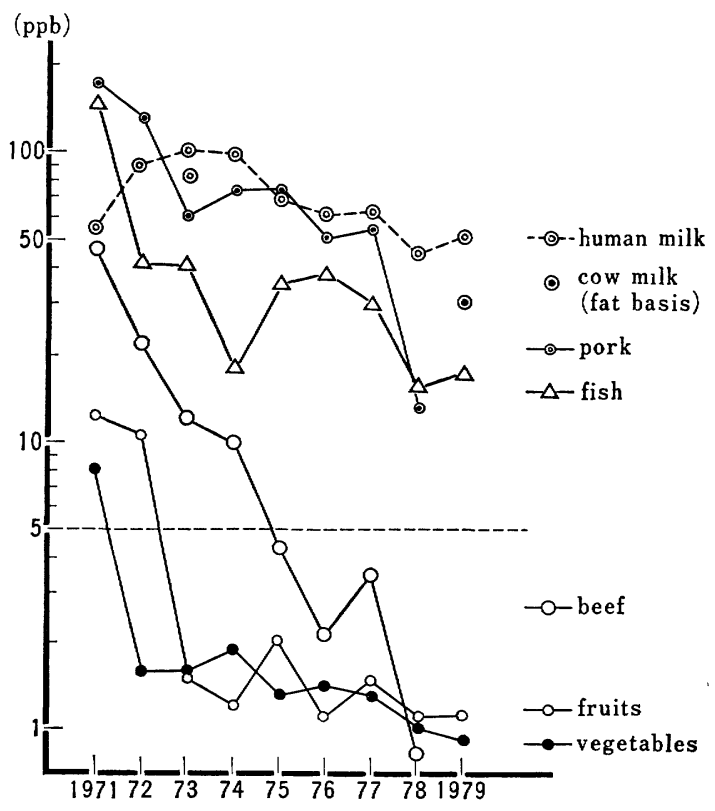

図 6 食品中の総 DDT (pp'-DDT, $p p^{\prime}$-DDE, $\boldsymbol{p} \boldsymbol{p}^{\prime}$-DDD, $\boldsymbol{o p}$-DDT) 濃度の推移 (全国平均值) 


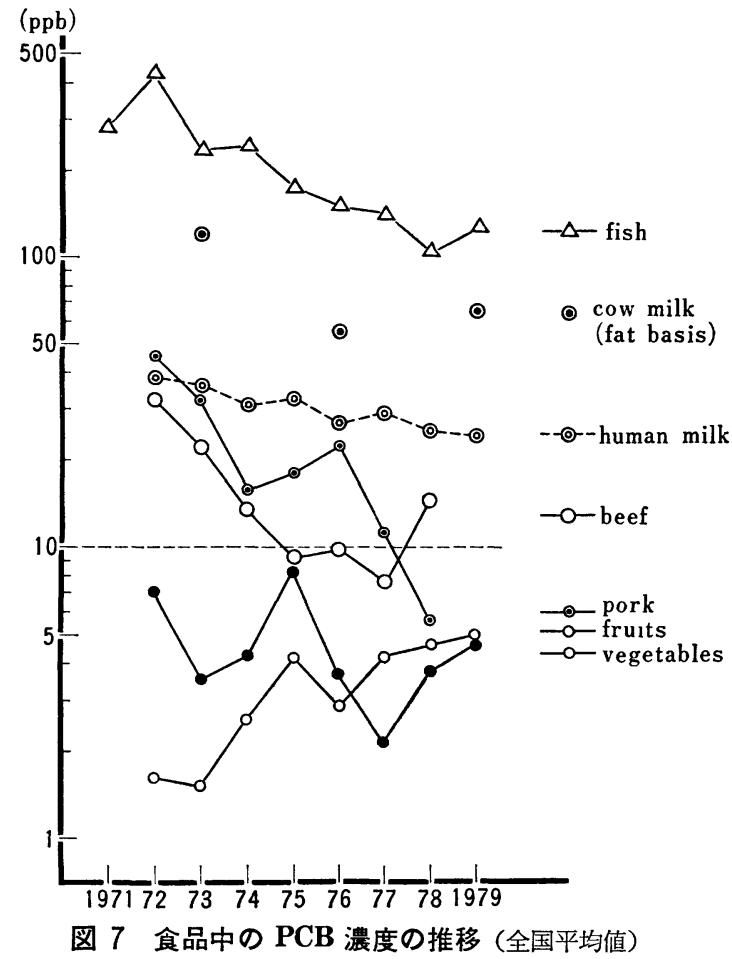

図中の $5 \mathrm{ppb}$ のところに引いた点線は分析の検出限 界を示す．母乳と魚を除けば（牛乳は fat basis の值で あるから実際の牛乳中の濃度はこの約 $1 / 30$ になる), 他 の食品中の有機塩素化合物はすでに，あるいはあと数年
を経ずして，検出限界以下に達することが子想される。

\section{2）食品中の童金属分布と化学形態}

動植物は長い進化の過程で, 自らの生育する環境中に ある金属の有する触媒能を利用するため，それらを体内 に積極的にとり込み，それに特殊なたん白構造を結合さ せて活性を $10^{10}$ 倍にも上昇させて利用している. カタ ラーゼの鉄, グルタチオンペルオキシダーゼのセレンな ぞ，多くの例にその事実をみることができる。したがっ て, 動植物中の重金属, 特に水銀, アンチモン, 鉛の 3 種以外の重金属は, 存在したとしても必ずしも污染物と はいえない，従来から特に含量の高いことが知られてい るもの, たとえば海藻のヒ素, カキの亜鉛, バイのカド ミウムなどは，ある必要性をもってとり込まれているよ らにもみ觉るし，そういう場合には，摂取しても有害性 を示さないのではないかとも思われる。

このような観点から, 最近重金属の食品中の存在化学 形態の研究が盛んになっている. 重金属に関するモ二タ リングデータを整理し，同系統の食品中に含まれる重金 属の分析データを集め, 最小值から最大值まで並べて, それを件数で 10 等分したとき, 特定食品の分析值が, 10 等分したどこに分布しているかを見ると，表のよう になる.表は甲凯・軟体類についてカドミウム含量の分

甲殻類・軟体類におけるカドミウム分析値分布 (件数の分布百分率)

\begin{tabular}{|c|c|c|c|c|c|c|c|c|c|c|c|c|c|c|c|c|c|}
\hline & & & \multicolumn{2}{|c|}{$\begin{array}{c}\text { 最小值 } \\
0\end{array}$} & \multicolumn{3}{|c|}{$\begin{array}{ccc}10 \% \text { 值 } & 20 \% \text { 值 } & 30 \% \text { 值 } \\
0.02 & 0.048 & 0.07\end{array}$} & $\begin{array}{c}40 \% \text { 值 } \\
0.1\end{array}$ & $\begin{array}{r}50 \% 1 \\
0.15\end{array}$ & $\begin{array}{l}\text { 6值 } 60 \\
150\end{array}$ & $\begin{array}{l}0 \% \text { 值 } \\
0.24\end{array}$ & $\begin{array}{c}70 \% \text { 値 } \\
0.36\end{array}$ & $\begin{array}{c}80 \% \text { 值 } \\
0.54\end{array}$ & $\begin{array}{c}90 \% \text { 值 } \\
1.0\end{array}$ & $\begin{array}{c}\text { 最大暄 } \\
135\end{array}$ & \multicolumn{2}{|c|}{$(\mathrm{ppm})$} \\
\hline 食 & 品 & 名 & & データ数 & 最小値 & $\sim 1$ & $0 \% \sim$ & $20 \%$ & $-30 \%$ & $\% \sim 4$ & $40 \%$ & $\sim 50 \%$ & $\% \sim 60 \%$ & $\% \sim 70 \%$ & $\% \sim 80 \%$ & $\sim 9$ & $0 \%$ ～最大值 \\
\hline W & & & か & 135 & & 17.8 & 18.5 & 17. & & 4.4 & & 9.6 & 7.4 & 5.2 & 4.4 & 8.1 & 7.4 \\
\hline す & る & めい & か & 37 & & 0 & 13.5 & 13. & & 5.4 & & 2.7 & 2.7 & 13.5 & 10.8 & 10.8 & 27.0 \\
\hline 之 & & & び & 70 & & 42.9 & 20.0 & 8. & 6 & 10.0 & & 7.1 & 5.7 & 2.9 & 0 & 0 & 2.9 \\
\hline 芝 & & え & び & 15 & & 60.0 & 40.0 & 0 & & 0 & 0 & 0 & 0 & 0 & 0 & 0 & 0 \\
\hline か & & & に & 16 & & 6.3 & 12.5 & 6 . & 3 & 6.3 & & 2.5 & 12.5 & 6.3 & 0 & 12.5 & 25.0 \\
\hline 毛 & & が & に & 18 & & 0 & 0 & 0 & & 0 & & 2.2 & 16.7 & 11.1 & 0 & 11.1 & 38.9 \\
\hline た & & & $こ$ & 36 & & 30.6 & 27.8 & 30. & & 0 & & 5.6 & 5.6 & 0 & 0 & 0 & 0 \\
\hline な & & ま & $こ$ & 10 & & 40.0 & 30.0 & 30. & & 0 & 0 & 0 & 0 & 0 & 0 & 0 & 0 \\
\hline あ & & さ & $\eta$ & 475 & & 2.7 & 19. 2 & 14. & & 25.5 & & 2.9 & 12.4 & 1.9 & 0.4 & 0 & 0 \\
\hline あ & & わ & び & 15 & & 0 & 6.7 & 20. & & 6.7 & & 6.7 & 6.7 & 0 & 6.7 & 20.0 & 26.7 \\
\hline か & & & き & 284 & & 0.7 & 0.4 & 0 & & 2.1 & & 2.5 & 10.9 & 29.6 & 32.7 & 18.0 & 3.2 \\
\hline L & & じ & Zx & 107 & & 0 & 0.9 & 2. & 8 & 1.9 & & 8.4 & 21.5 & 25.2 & 21.5 & 14.0 & 3.7 \\
\hline さ & & ざ & 壳 & 13 & & 7.7 & 7.7 & 0 & & 0 & 0 & 0 & 0 & 0 & 15.4 & 7.7 & 61.5 \\
\hline 長 & 太 & 郎 & 貝 & 93 & & 0 & 0 & 0 & & 0 & & 4.3 & 6.5 & 11.8 & 18.3 & 32.3 & 26.9 \\
\hline ほ & た & $\tau$ & 貝 & 62 & & 1.6 & 0 & 0 & & 1.6 & 0 & 0 & 1.6 & 6.5 & 4.8 & 4.8 & 79.0 \\
\hline は & ま & く & $\eta$ & 18 & & 11.1 & 5.6 & 0 & & 0 & & 1.1 & 16.7 & 11.1 & 5.6 & 11.1 & 27.8 \\
\hline ば & & & $w$ & 5 & & 0 & 0 & 0 & & 0 & 0 & 0 & 0 & 0 & 0 & 0 & 100.0 \\
\hline ま & か & き & 貝 & 20 & & 0 & 0 & 0 & & 0 & & 5.0 & 5.0 & 0 & 15.0 & 50.0 & 25.0 \\
\hline
\end{tabular}

10\%值，20\%值……は，それぞれ 10 パーセンタイル值，20パーセンタイル值……を表わす. 
布を示したものである．近縁の食品の間でも色々な特徵 がらかがえる.すなわち，ばいが特異的に高いカドミウ ム含量を示すことは前にも述べたが，あさりに比べてし じみが有意に高い汪うに分布している。たこ，なまこは 低く，するめいかには含量が高いものが多い。このよう な解析から, 化学形態研究の材料探しをするのも一つの 方法である.

\section{$*$}

モニタリングデータは地域特異性があり，またその時
代に特有の值でもある．普遍性のない理論は自然科学に おける原理にはなりえないところから，モニタリングは 従来学問的価値がそれほど認められていなかった。しか し, 一旦環境科学あるいは生活科学の立場に立てば, モ ニタリングデータがすべての計画と解析の基礎であるこ とは明らかである. われわれの学問研究の成果をわれわ れ自身の社会に還元するためにも, あらゆる意味でのモ ニタリングを強化し, 価值あるデータの蓄積をはかりた いと考える.
プロフィル

井村 伸正 (Nobumasa Imura) 昭 和10年10月 24 日生 <略歴>昭和 34 年東京 大学薬学部薬学科卒業 $/ 39$ 年同大学大学 院博士課程 (薬学専攻) 修了/40年同大 学助手 $/ 50$ 年北里大学薬学部教授, 現在 にいたる.この間， 41〜43年ニューヨー ク大学医学部生化学教室研究員<研究テ 一マと抱負> (1)重金属の毒性学, 特に水 銀毒性の発現機序に関する生化学, (2)水 銀化合物の biotransformation, (3)核酸 の構造と機能に関する分子生物学

上田誠之助 (Seinosuke Ueda) 大正 10 年 11 月 30 日生 <略歴>昭和 20 年九州帝 国大学農学部農芸化学科卒業／同大学農 学部助手, 助教授を経て昭和 42 年同大学 食糧化学工学科教 授く研究テーマと抱 負>䁔造食品が酵素仕込みででさる日を 夢みていますく趣味〉一人旅

内山充 (Mitsuru Uchiyama) 昭 和 5 年 3 月 1 日生<略歴>昭和 28 年東京 大学医学部薬学科卒業 $/ 34$ 年東北大学医 学部薬学科助教授 $/ 43$ 年同大学薬学部教 授(衛生化学) $/ 49$ 年国立衛生試験所食品 部長, 現在にいたるく研究テーマと抱 負>現在は食品中の有害物の化学毒理学 と並んで食品あるいは生体成分の变質の 分析とその意義づけ，あるいは食品中の 特殊成分の有効性などに與味をもってい る

遠藤章 (Akira Endo) 昭和 8 年 11 月 14 日生 $<$ 略歴 $>$ 昭和 32 年東北大学農 学部農芸化学科卒業／同年三共株式会社 入社. 主任研究員, 研究室長を释て, 54 年東京農工大学農学部助教授, 現在にい
たる. 41 年農芸化学賞, $41 \sim 43$ 年米国了 インシュタイン医科大学留学, 53 年から Biochim. Biophys. Acta のレフェリー <研究テーマと抱負>生理活性物質, 特 に薬理作用をもった微生物代謝産物を探 し出し, 医薬関連製品として開発するこ とを研究テーマとする. 現在動脈硬化 (コレステロール低下剤)，糖尿病（血糖 低下剂)，虫歯等に関連したものを主に 手がけている. 探し方さえ的を得ておれ ば微生物からどんな生理活性物質も発見 できるすのと信じて研究しているく趣 味>家庭菜園 (畑 50 坪を耕作中), 山步 き，美味しいご馳走を食べながらお酒を 飲さこと

奥田 智子 (Tomoko Okuda) 昭和 7 年 6 月 23 日生 <略歷>昭和 30 年お茶の 水女子大学理学部化学科卒業/同年石炭 総合研究所 $/ 37$ 年東洋大学工学部助手 $/$ 42 年国立がんセンター研究所 $/ 50$ 年東北 大学抗酸菌病研究所助教授, 現在にいた るく研究テーマと抱負 > 補体活性化と抗 腫㾮性, 補体の比較免疫<趣味>山歩き （山草を賞でつつ）

鈴木たね子 (Taneko Suzuki) 昭和 元年 11 月 12 日生 $<$ 略歴 $>$ 昭和 23 年東邦大 学楽学部薬学科卒業 $/ 35$ 年九州大学農学 博士/水産庁西海区水産研究所を程て, 現在東海区水産研究所蛋白化学研究室長 <研究テーマと抱負〉魚介肉タンパクの 変性による物性の変化. マリンビーフを 洋上で加工できる工船の開発に向けて組 織をアレンジしているく趣味〉ネコの飼 育 (特にノラネコ), 宝生流能楽
高㛢 章 (Akira Takahashi) 昭 和 24 年11月 9 日生<略歴>昭和 48 年東京 薬科大学製薬学科卒業/同年東京都精神 医学研究所神経化学勤務く研究テーマと 抱負>シナプスにおける物質代謝, coated vesicle の生理的機能について. 神 程系と物質代謝の関連に興味があるく趣 味>山歩き, レコード鑑賞

高楿 克忠 (Katsutada Takahashi) 昭和 13 年 3 月 4 日生 <略歴 > 昭和 36 年大 阪府立大学農学部農芸化学科卒業 $/ 41$ 年 同大学大学院博士課程修了/同年米国農 務省海外援助資金研究員 $/ 44$ 年大阪府立 大学農学部勤務, 現在にいたるく研究テ 一マと抱負〉よき師，よき先輩，よき同 僚にめぐまれ，生体反応系の熱測定をず っと続けてきました. 53〜55年プリバロ フ DSC の技術を習得するため米国エー ル大学に参りましたが，それをあとに， とびきり精度の高い熱容量差測定装置を つくるのが，現在の切実な課題ですく趣 味>テニス. ただしこの 7 月エールでラ イバルに挑戦を受け，それがもとでテニ スエルボウに患り, 目下左腕療養中

高楮 進 (Susumu Y. Takahashı) 昭和13年 4 月 11 日生 $<$ 略歴 $>$ 昭和 40 年東 京都立大学大学院理学研究科 (生物学) を経て名古屋大学理学部助手, 現在にい たるく研究テーマと抱負>c-GMP 依存 性プロテインキナーゼの作用と調節. そ の他, JH の生合成および作用機構に関 心をむっているく趣味>テニスとビール 